\title{
Altered peripheral nerve function resulting from haemodialysis
}

\author{
E. STANLEY, J. C. BROWN, AND J. S. PRYOR \\ From the Departments of Neurology and Medicine, Norfolk and Norwich Hospital, Norwich, Norfolk
}

SUMMARY The amplitudes of muscle and nerve action potentials evoked by median nerve stimulation were recorded just before and immediately after haemodialysis. These revealed a growth of action potential amplitude during dialysis. It is suggested that some component of the defective peripheral nerve function that inevitably accompanies uraemia is temporarily improved during dialysis.

The advent of maintenance haemodialysis has brought into prominence the neuropathy associated with renal failure, in which there is axonal degeneration and segmental demyelination (Dayan et al., 1970). However, much of the altered peripheral nerve function in this condition cannot be dependent upon such structural changes: after transplantation, the increase in conduction velocity occurs more rapidly than could be explained by recovery of segmental demyelination (Ibrahim et al., 1974; Nielsen, 1974a,b; Bolton, 1976). The reduction in conduction velocity is more evident in proximal than distal segments in uraemic patients (Nielsen, 1973), in contrast to the findings in demyelinating neuropathies.

While rapid improvement in peripheral nerve function after transplantation is beyond dispute, the precise effect of haemodialysis is still unclear. It may arrest the progressive decrease in conduction velocity which accompanies renal failure (Nielsen, 1974c), yet the neuropathy may develop explosively only when haemodialysis has been started (Tenckhoff et al., 1965). Does a single haemodialysis have any effect on peripheral nerve function? Studies just before and immediately after haemodialysis should answer this question. To date, these have been restricted to clinical observations and conduction velocity estimations where no significant change has been noted (Jebson et al., 1967). We have, therefore, measured the evoked muscle and nerve action potential amplitude from exactly the same sites before and after haemodialysis in uraemic patients to show the effect of a single dialysis.

\section{Methods}

Studies were carried out on 10 occasions in six patients whose clinical and dialysis details are shown in Table 1. Patient 1 had a moderately severe sensorymotor peripheral neuropathy principally involving the lower extremities. Patients $2-6$ had no clinical evidence of peripheral nerve dysfunction.

The median nerve was stimulated through surface electrodes at the wrist. The cathode was a silversilver chloride coated disc of $1 \mathrm{~cm}$ diameter over the course of the nerve on the volar aspect. The anode was a silver-silver chloride coated strip $5 \mathrm{~cm} \times 2 \mathrm{~cm}$ over the dorsal aspect. Supramaximal electric stimuli of $0.2 \mathrm{~ms}$ duration were delivered from a Devices digitimer through a gated pulse generator.

Evoked action potential recordings were made in turn from each of three sites (Fig. 1): (1) sensory potentials from the digital nerves of the middle finger (an antidromic impulse) through a pair of Disa Velcron tip surface ring electrodes; (2) potentials of the abductor pollicis brevis muscle recorded between surface disc electrodes of $1 \mathrm{~cm}$ diameter, one over the belly of the muscle and the other as a reference electrode at the tip of the thumb; (3) mixed (combined orthodromic sensory and antidromic motor) action potentials recorded from the median nerve at the elbow through Disa subcutaneous recording needle electrodes at the site where the nerve was most accessible, previously located by a searching percutaneous stimulating electrode. The active recording electrode was inserted over the course of the nerve and the reference electrode $1 \mathrm{~cm}$ lateral to it.

The evoked action potentials were amplified by a Medelec 2A3 parametric amplifier and displayed on a Tektronix 564B storage oscilloscope, nerve action 
Table 1 Details of patients

\begin{tabular}{|c|c|c|c|}
\hline Paticnt & $\begin{array}{l}\text { Age }(y r), \\
\operatorname{sex}\end{array}$ & Dialysis details & Clinical cordition \\
\hline 1 & $\begin{array}{l}63 \\
M\end{array}$ & $\begin{array}{l}\text { Ultra flow II dialyser } \\
\text { RSP machine } \\
6 \mathrm{~h} \text {, three times per week }\end{array}$ & $\begin{array}{l}\text { Proliferative } \mathrm{GN}^{*} \\
\text { (crescent type) } \\
\text { Anuric }\end{array}$ \\
\hline 2 & $\begin{array}{l}18 \\
M\end{array}$ & $\begin{array}{l}\text { Ultra flow II dialyser } \\
\text { REDY machine } \\
6 \mathrm{~h} \text {, twice weekly }\end{array}$ & $\begin{array}{l}\text { Membrane- } \\
\text { proliferative GN } \\
\text { Anuric }\end{array}$ \\
\hline 3 & $\begin{array}{l}47 \\
\mathbf{M}\end{array}$ & $\begin{array}{l}\text { Ultra flow II dialyser } \\
\text { REDY machine } \\
6 \mathrm{~h} \text {, twice weekly }\end{array}$ & $\begin{array}{l}\text { Hypertensive renal } \\
\text { failure } \\
\text { Passing } 500 \mathrm{ml} \text { urine } \\
\text { daily at time of study }\end{array}$ \\
\hline 4 & $\begin{array}{l}22 \\
F\end{array}$ & $\begin{array}{l}\text { Ultra flow II dialyser } \\
\text { REDY machine } \\
6 \mathrm{~h} \text {, once weekly }\end{array}$ & $\begin{array}{l}\text { Chronic GN } \\
\text { Still passing } 21 \\
\text { urine at time of study }\end{array}$ \\
\hline 5 & $\begin{array}{l}40 \\
M\end{array}$ & $\begin{array}{l}\text { Ultra flow II dialyser } \\
\text { RSP machine } \\
6 \mathrm{~h} \text {, twice weekly }\end{array}$ & $\begin{array}{l}\text { Membranous GN } \\
\text { Passing } 11 \text { urine } \\
\text { daily at time of study }\end{array}$ \\
\hline 6 & $\begin{array}{l}49 \\
F\end{array}$ & $\begin{array}{l}\text { Ultra flow II dialyser } \\
\text { RSP machine } \\
6 \mathrm{~h} \text { per week }\end{array}$ & $\begin{array}{l}\text { Malignant } \\
\text { hypertension and } \\
\text { renal failure } \\
\text { Passing } 500 \mathrm{ml} \text { urine } \\
\text { daily at time of study }\end{array}$ \\
\hline
\end{tabular}

*Glomerulonephritis.

MEDIAN NERVE

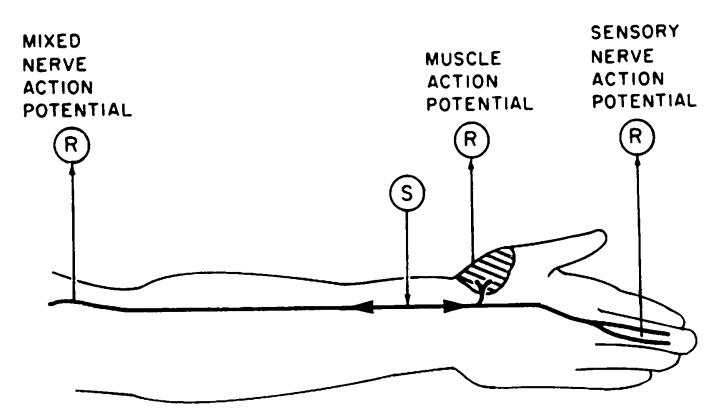

Fig. 1 Stimulating and recording sites (see text).

potentials being first fed through a Disa 14B15 input transformer.

Patients were first studied during the hour before starting dialysis. The exact positions of each of the stimulating and recording sites were marked with indelible pencil and, during the hour after completion of dialysis, the electrodes were reapplied at these sites and the procedure repeated. The ambient temperature was maintained at $20-22^{\circ} \mathrm{C}$. The surface temperature at the base of the middle finger was recorded using a thermocouple during the predialysis recording. After dialysis, the limb was either cooled or warmed so that the temperature was the same during the latter recording.

In addition to the study of the responses evoked by supramaximal nerve stimulation, the excitability of the median nerve was compared before and after dialysis by noting the stimulus current required to evoke a threshold (smallest recognisable) response, $50 \%$ of the maximal response, and the maximal response for each of three types of potential. Finally, the motor and sensory conduction velocity was estimated in the forearm segment of the median nerve and terminal latencies noted.

\section{Results}

Table 2 shows the increase in evoked action potential generally induced by dialysis. Amplitudes recorded from the same site on different days (patients 2 and 6) were different as neither the recording sites nor the temperature were identical on different days, although these were identical in each study before and after dialysis on the same day.

There were only two exceptions each to this rise in the muscle and sensory nerve recordings. There was growth of the mixed nerve action potential in all cases where a recognisable action potential could be seen before dialysis (eight out of ten occasions). Figure 2 indicates that this increase in mixed nerve action potential is proportionately greater than that of the muscle or sensory nerve action potentials.

Measurement of motor conduction velocity and of sensory velocity (six recordings) showed no significant difference before as compared with after dialysis (Fig. 3). Before dialysis, the mean motor conduction velocity was $45.9 \mathrm{~m} / \mathrm{s}$ and the sensory was $46.6 \mathrm{~m} / \mathrm{s}$. After dialysis, the mean motor velocity was $45.5 \mathrm{~m} / \mathrm{s}$ and the mean sensory velocity was $47.0 \mathrm{~m} / \mathrm{s}$. Motor and sensory terminal latencies were usually reduced after dialysis but these changes were not significantly different. Similarly, the excitability of the median nerve was not affected significantly since the stimulus current required to evoke the different types of action potential was the same before and after dialysis.

\section{Discussion}

Peripheral nerve function is defective in most, if not all, patients with chronic renal failure in that conduction velocities are reduced (Preswick and Jeremy, 1964) and segmental demyelination can be seen (Bolton, 1976). Furthermore, improvement in nerve function after transplantation is now well-documented (Ibrahim et al., 1974; Nielsen, 1974a,b; Bolton, 1976). This study shows that haemodialysis also causes improvement, though this is only partial and transient. There are four possible explanations for this. Firstly, the metabolic and electrolyte changes consequent upon dialysis might alter electrical conductance between nerve and recording electrode. However, were this the case, a similar alteration would be expected between a stimulating 
Table 2 Action potential amplitudes before and after dialysis

\begin{tabular}{|c|c|c|c|c|c|c|c|c|c|c|}
\hline \multirow[t]{2}{*}{ Patient } & \multicolumn{3}{|c|}{ Pre-dialysis amplitude } & \multicolumn{4}{|c|}{ Post-dialysis amplitude } & \multicolumn{3}{|c|}{ Increase in post-dialysis amplitude } \\
\hline & $\begin{array}{l}\text { Mixed } \\
\text { nerve action } \\
\text { potential } \\
\mu V\end{array}$ & $\begin{array}{l}\text { Muscle } \\
\text { action } \\
\text { potential } \\
m V\end{array}$ & $\begin{array}{l}\text { Sensory } \\
\text { nerve action } \\
\text { potential } \\
\mu V\end{array}$ & $\begin{array}{l}\text { Mixed } \\
\text { nerve action } \\
\text { potential } \\
\mu V\end{array}$ & $\begin{array}{l}\text { Muscle } \\
\text { action } \\
\text { potential } \\
m V\end{array}$ & $\begin{array}{l}\text { Sensory } \\
\text { nerve action } \\
\text { potential } \\
\mu V\end{array}$ & & $\begin{array}{l}\text { Mixed } \\
\text { nerve action } \\
\text { potential } \\
\mu V\end{array}$ & $\begin{array}{l}\text { Muscle } \\
\text { action } \\
\text { potential } \\
m V\end{array}$ & $\begin{array}{l}\text { Sensory } \\
\text { nerve action } \\
\text { potential } \\
\mu V\end{array}$ \\
\hline 1 & 10.5 & 16.0 & 26.0 & 13.0 & 20.0 & 37.0 & & 2.5 & 4.0 & 11.0 \\
\hline \multirow[t]{2}{*}{2} & 15.5 & 20.0 & 30.5 & 27.0 & 26.5 & 48.0 & & 11.5 & 6.5 & 17.5 \\
\hline & 11.0 & 11.0 & 18.0 & 15.0 & 10.6 & 20.0 & & 4.0 & -0.4 & 2.0 \\
\hline 3 & 15.5 & 6.7 & 48.0 & 24.5 & 10.0 & 49.0 & & 9.0 & 3.3 & 1.0 \\
\hline \multirow[t]{2}{*}{4} & 10.4 & 16.0 & 130.0 & 13.0 & 19.5 & 130.0 & & 2.6 & 3.5 & 0.0 \\
\hline & - & 8.4 & 72.0 & - & 11.8 & 135.0 & & - & 3.4 & 73.0 \\
\hline \multirow[t]{2}{*}{5} & - & 3.4 & 66.0 & - & 4.4 & 76.0 & & - & 1.0 & 10.0 \\
\hline & 4.0 & 12.0 & 38.0 & 5.2 & 11.2 & 57.0 & & 1.2 & -0.8 & 19.0 \\
\hline \multirow[t]{2}{*}{6} & 5.0 & 7.1 & 52.0 & 11.7 & 10.6 & 46.0 & & 6.7 & 3.5 & -6.0 \\
\hline & 10.7 & 6.5 & 37.0 & 17.0 & 6.8 & 44.0 & & 6.3 & 0.3 & 7.0 \\
\hline Mean & 10.3 & 10.7 & 51.8 & 15.8 & 12.1 & 64.2 & & 5.5 & 2.4 & 12.5 \\
\hline \multirow[t]{4}{*}{ SD } & 4.2 & 5.3 & 32.3 & 7.1 & 6.4 & 38.7 & & 3.6 & 2.3 & 19.4 \\
\hline & & & & & & & $t=$ & 4.36 & 3.33 & 2.03 \\
\hline & & & & & & & $\mathrm{df}=$ & 7 & 9 & 9 \\
\hline & & & & & & & & $P<0.01$ & $P<0.01$ & $P>0.10$ \\
\hline
\end{tabular}

$P=$ probability of no change in amplitude.

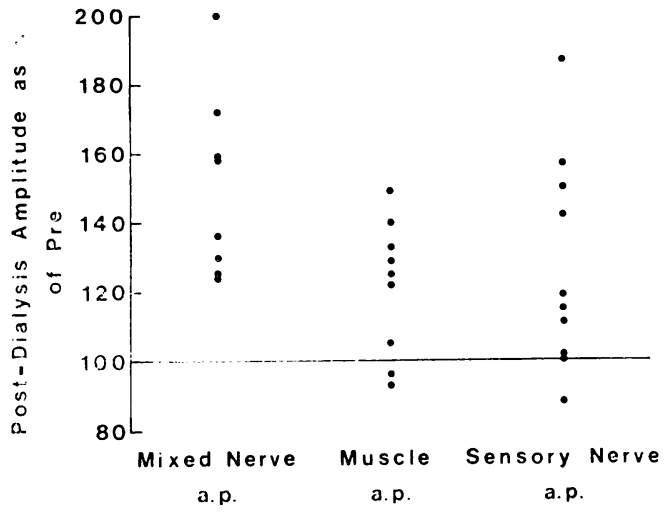

Fig. 2 Effect of dialysis upon amplitude of evoked action potentials.

electrode and nerve, leading to a change in excitability. In fact, excitability was not affected by dialysis.

Secondly, the rise in amplitude of the compound action potential after dialysis might be due to changes in conduction velocity leading to better synchronisation. This seems unlikely for the following reasons. No change in conduction velocity occurred in the forearm segment of the median nerve during dialysis. No consistent changes in terminal latency occurred. Dialysis resulted in no significant change in the duration of the action potentials. Finally, where better synchronisation is induced in peripheral nerves by cooling, any increase in action potential amplitude is accompanied by a reduction in conduction velocity and prolongation of terminal latency (Ritchie and Straub, 1956 and own observations). However, after

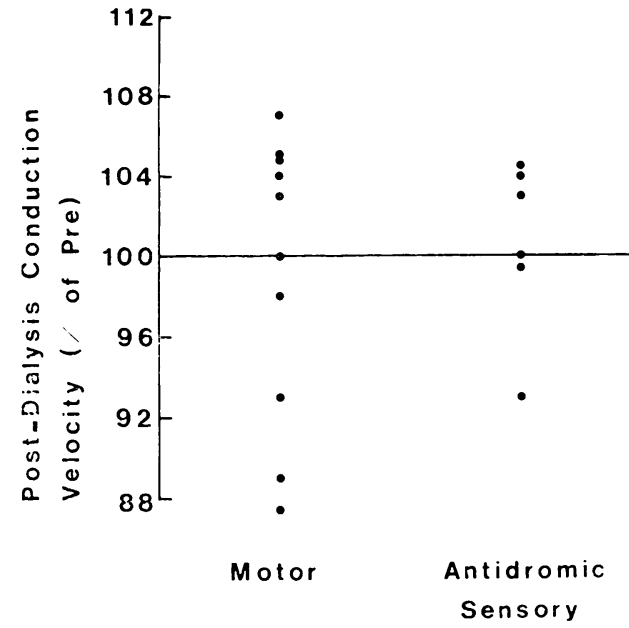

Fig. 3 Effect of dialysis upon conduction velocity.

dialysis velocities were not reduced nor were latencies prolonged.

Thirdly, the number of functioning fibres in the median nerve might be increased by dialysis. While function of a proportion of nerve fibres will be permanently depressed by uraemia and a further preportion may be functioning normally, the function in some fibres may be at a critical level whereby the changes in concentration of certain metabolites induced by dialysis might determine their capacity to generate an action potential.

Fourthly, the amplitude of individual muscle and nerve fibre action potentials might increase during dialysis. Since intracellular sodium concentration is in- 
creased in uraemia, the resting membrane potential is reduced (Bolt et al., 1963). Hence, if a dialysable humoral factor in uraemic serum is responsible for the toxic impairment of axon membrane function, a transient reduction in its concentration may allow such improvement to take place, perhaps through effects on sodium $^{+}$-potassium ${ }^{+}$activated ATPase(Welt et al., 1964). We are not able at present to conclude which of the two latter possibilities is responsible for the rise in action potential amplitude. It is possible that both phenomena are occurring.

The nature of the metabolic or toxic defect responsible for the altered peripheral nerve function in uraemia must next be considered. In our studies, as in those of Nielsen and Winkel (1971), there was no correlation between peripheral nerve function and blood urea or creatinine levels. It is difficult to relate the changes in nerve function to these or to serum electrolyte levels, particularly since the twin coil type of dialysis, rapidly correcting defects of urea and electrolyte concentration, appears to be less effective in preventing peripheral nerve damage than the slow Kiil type of dialysis (Tenckhoff et al., 1965).

A number of metabolic disorders in uraemia have been related to peripheral nerve dysfunction (Lonergan et al., 1971; Clements et al., 1973; London et al., 1975). It is probable that the accumulation of intermediate molecular weight substances ('middle molecules') is responsible for the peripheral nerve damage (Babb et al., 1971). Such molecules cross the dialysing membrane only slowly and are thus more effectively cleared when dialysis time is prolonged than when flow rate is increased. This may well explain the deterioration in peripheral nerve function that may occur despite apparently effective dialysis. Our findings would support the contention that the appearance of features of a peripheral neuropathy is an indication for an increase in the frequency and duration of dialysis, or the use of dialysing membranes with higher 'middle molecule' clearance rates.

It is not yet clear to what extent this disordered peripheral nerve function in uraemia is related to the appearance of the neuropathy: the reduction in conduction velocity noted by Nielsen (1973) is as marked in the upper limbs as in the lower, and is more evident in proximal segments of the nerve, yet clinical features of a neuropathy are first manifest in distal segments of the lower limbs. The abnormality we have shown is also greater at the proximal site, and is apparently unrelated to the clinical features of neuropathy.

Although conduction velocity measurement has been of value in showing altered peripheral nerve function in uraemia, the changes related to dialysis are revealed only by measurement of evoked action potential amplitude. Scrutiny of this, and of such aspects of peripheral nerve function as excitability and refractory period, should provide more information about the peripheral nerve in metabolic disorders.

We wish to thank Mrs M. Hutchings for secretarial assistance. This work was supported by a grant from the East Anglian Regional Health Authority Research Fund and by the Muscular Dystrophy Group of Great Britain.

\section{References}

Babb, A. L., Popovich, R. P., Christopher, T. G., and Scribner, B. H. (1971). The genesis of the square meter-hour hypothesis. Transactions of the American Society for Artificial Internal Organs, 17, 81-91.

Bolt, H. D., Riecker, G., and Rohl, D. (1963). Measurements of membrane potential of individual muscle cells in normal men and patients with renal insufficiency. 2nd Internal Congress of Nephrology, 78, 114.

Bolton, C. F. (1976). Electrophysiologic changes in uremic neuropathy after successful renal transplantation. Neurology (Minneap.), 26, 152-161.

Clements, R. S., De Jesus, P. V., and Winegrad, A. I (1973). Raised plasma myoinositol levels in uraemia and experimental neuropathy. Lancet, 1, 1137-1141.

Dayan, A. D., Gardner-Thorpe, C., Down, P. F., and Gleadle, R. I. (1970). Peripheral neuropathy in uremia Neurology (Minneap.), 20, 649-658.

Ibrahim, M. M., Barnes, A. D., Crosland, J. M., Dawson Edwards, P., and Newman, C. E. (1974). Effect of renal transplantation on uraemic neuropathy. Lancet, 11 739-742.

Jebson, R. H., Tenckhoff, H., and Honet, J. C. (1967). Natural history of uremic polyneuropathy and effects of dialysis. New England Journal of Medicine, 277, 327-333.

London, G. M., Nordmann, Y., Safar, M. E., Metral, S., and Milliez, P. (1975). Free erythrocyte protoporphyrin level and nerve conduction velocity in end-stage renal disease. British Medical Journal, 4, 324-325.

Lonergan, E. T., Semar, M., Sterzel, R. B., Treser, F., Needle, M. A., Voyles, L., and Lange, K. (1971). Erythrocyte transketolase activity in dialysed patients. New England Journal of Medicine, 284, 1399-1403.

Nielsen, V. K., and Winkel, P. (1971). The peripheral nerve function in chronic renal failure. III A multivariate statistical analysis of factors presumed to affect the development of clinical neuropathy. Acta Medica Scandinavica, 190, 119-125.

Nielsen, V. K. (1973). The peripheral nerve function in chronic renal failure. V Sensory and motor conduction velocity. Acta Medica Scandinavica, 194, 445-454.

Nielsen, V. K. (1974a). The peripheral nerve function in chronic renal failure. VIII Recovery after renal transplantation. Clinical aspects. Acta Medica Scandinavica, 195, 163-170.

Nielsen, V. K. (1974b). The peripheral nerve function in chronic renal failure. IX Recovery after renal transplantation. Electrophysiological aspects (sensory and 
motor conduction). Acta Medica Scandinavica, 195, 171-180.

Nielsen, V. K. (1974c). The peripheral nerve function in chronic renal failure. VII Longitudinal course during terminal renal failure and regular haemodialysis. Acta Medica Scandinavica, 195, 155-162.

Preswick, G., and Jeremy, D. (1964). Subclinical polyneuropathy in renal insufficiency. Lancet, 11, 731-732.

Ritchie, J. M., and Straub, R. W. (1956). The effect of cooling on the size of the action potential of mammalian non-medullated fibres. Journal of Physiology, 134, 712-717.

Tenckhoff, H. A., Boen, F. S. T., Jebson, R. H., and Spiegler, J. H. (1965). Polyneuropathy in chronic renal failure. Journal of the American Medical Association, 192, 1121-1124.

Welt, L. G., Sachs, J. R., and McManus, T. J. (1964). An ion transport defect in erythrocytes from uremic subjects. Transactions of the Association of American Physicians, 77, 169. 